\title{
Peran Notaris Dalam Pembuatan Kontrak Bisnis, Pengabdian Masyarakat Pada Fakultas Hukum Universitas Jambi
}

\author{
Yetniwati, Elita Rahmi, Hartati \\ Magister Kenotariatan, Universitas Jambi
}

\begin{abstract}
Abstrak: Perkembangan dunia bisnis selalu meningkat untuk menunjang pembangunan . Banyaknya transaksitransaksi yang dilakukan oleh pelaku usaha membutuhkan adanya kepastian hukum dalam kontrak atau perjanjian yang dibuat oleh para pihak yang terkait dengan bisnis. Oleh karenanya, untuk melihat fungsi dari notaris dalam dunia bisnis, maka perlu dilakukan penyuluhan kepada mahasiswa Strata 1(sarjana) agar mereka mengetahui muatan materi hukum yang dipelajari di Prodi Kenotariatan Program Pascasarjana Universitas Jambi. Adapun lokasi sosialisasi yang dipilih adalah Fakultas Hukum Lancang Kuning Pekanbaru, Provinsi Riau yang mendidik banyak mahasiswa. Alasan pemilihan lokasi adalah karena belum adanya pendidikan kenotariatan di Fakultas Hukum Lancang Kuning Pekanbaru. Sebagai provinsi yang terdekat dengan Universitas Jambi diharapkan mereka dapat melanjutkan pendidikan di Universitas Jambi.
\end{abstract}

\section{PENDAHULUAN}

\subsection{Analisis Situasi}

Perkembangan dunia bisnis selalu meningkat untuk menunjang pembangunan . Banyaknya transaksi-transaksi yang dilakukan oleh pelaku usaha membutuhkan adanya kepastian hukum dalam kontrak atau perjanjian yang dibuat oleh para pihak yang terkait dengan bisnis. Perjanjian-perjanjian dapat dibuat oleh para pihak dapat saja dalam bentuk lisan atau tertulis, akan tetapi dalam bentuk teertulis lebih memberikan kepastian hukum. Perjanjian secara tertulis terdiri dari akta dibawah tangan, dan akta otentik. Akta dibawah tangan dilakukan oleh kedua belah pihak dan ditanda tangani oleh kedua belah pihak sebagai tanda bukti adanya kesepakatan. Perjanjian dalam bentuk akta otentik akan memberikan kekuatan pembuktian yang kuat dibandingkan akta dibawah tangan. Akta otentik menurut Pasal $285 \mathrm{RBg} / 165$ HIR adalah surat yang dibuat menurut ketentuan undang-undang oleh atau dihadapan pejabat umum, yang berkuasa untuk membuat surat itu, memberikan bukti yang cukup bagi kedua belah pihak dan ahli warisnya dan sekalian orang yang mendapat hak dari padanya, tentang segala hal yang disebut surat itu, dan juga tentang yang tercantum dalam surat itu.

Pejabat umum dimaksud oleh pasal tersebut sesuai dengan ketentuan berlaku adalah notaris. Pengertian Notaris Menurut Pasal 1 angka (1) Undang-undang Nomor 2 Tahun 2014 tentang Perubahan Atas Tahun 2004 Undang-undang Nomor 30 Tahun 2004 tentang Jabatan Notaris menetapkan: notaris adalah pejabat umum yang berwenang untuk membuat akta otentik dan memiliki kewenangan lainnya sebagaimana dimaksud dalam Undang-Undang ini atau berdasarkan undang-undang lainnya. Akta yang dibuat oleh notaris bernama akta notaris . Akta Notaris yang selanjutnya disebut Akta adalah akta otentik yang dibuat oleh atau di hadapan Notaris menurut bentuk dan tata cara yang ditetapkan dalam Undang-Undang ini. Tingginya tingkat kekuatan pembuktian dari akta notaris berakibat banyaknya perjanjianperjanjian dalam lapangan bisnis dibuat dalam akta otentik.

Realita masyarakat menunjukan banyaknya notaris sebagai pejabat umum sangat dibutuhkan oleh masyarakat, terutama menyangkut bidang bisnis membuat profesi ini di gemari oleh sarjana hukum untuk melanjutkan pendidikan ke Program Studi Kenotariatan. 
Jumlah prodi kenotariat di Indonesia adalah 25 prodi yang dikelola PTN dan PTS ${ }^{1}$. Adanya isu Menteri Hukum dan HAM akan menutup penerimaan mahasiswa baru mulai tahun ajaran $2018^{2}$, akan menimbul respon pro dan kontra. Kelompok yang pro akan mengatakan, bahwa pendidikan MKn tidak selalu menjadi notaris, namun banyak profesi lain yang dapat ia raih. Meskipun lulusan Magister Kenotariatan tidak selalu menjadi notaris, ia bisa saja menjadi dosen, pejabat publik, bekerja di perusahaan swasta, sebagai pejabat pembuat akta tanah, konsultan kontrak, dan berbagai pekerjaan yang berurusan dengan kontrak.Dalam dunia bisnis notaris di pakai sebagai salah satu Profesi Penunjang Pasar Modal, sebagai profesi yang sangat diidamkan oleh para notaris, maka disini notaris berkopentesi melalui seleksi yang ketat.

Banyaknya fungsi dari notaris dalam dunia bisnis, maka perlu dilakukan penyuluhan kepada mahasiswa Strata 1(sarjana) agar mereka mengetahui muatan materi hukum yang dipelajari di Prodi Kenotariatan Program Pascasarjana Universitas Jambi. Adapun lokasi sosialisasi yang dipilih adalah Fakultas Hukum Lancang Kuning Pekanbaru, Propinsi Riau yang mendidik banyak mahasiswa. Alasan pemilihan lokasi adalah karena belum adanya pendidikan kenotariatan di Fakultas Hukum Lancang Kuning Pekanbaru. Sebagai propinsi yang terdekat dengan Universitas Jambi diharapkan mereka dapat melanjutkan pendidikan di Universitas Jambi.

\subsection{Perumusan Masalah}

a. Bagaimanakah peran notaris dalam pembuatan kontrak bisnis?

b. Bagaimanakah repon mahasiswa terhadap profesi notaris dewasa ini ?

\section{PEMBAHASAN}

Hasil dari kegiatan pengabdian kepada masyararakat dalam bentuk sosialisasi materi hukum dibidang PeranNotarisDalamPembuatanKontrakBisnis, sehingga kelompok sasaran dapat meningkat pengetahuannya. Disamping itu kelompok sasaran memberikan respon tentang materi yang disampaikan dengan metode tanya jawab. Adapun materi yang disampaikan sebagai berikut:

\subsection{Peran Notaris Dalam Pembuatan Kontrak Bisnis}

Para pembisnis melakukan kegiatan usahanya harus melakukan perjanjian-perjanjian atau dikenal dengan istilah kontrak yang melahirkan perikatan sebagai akibat hukumnya. Perbuatan hukum para pembisnis dimulai dari cara mendirikan badan usaha, kemudian melakaukan transaksi-transaksinya dalam melakukan kegiatan usahanya. Bentuk-bentuk badanusaha terdiri dari :

1) Badan usaha perseorangan

2) Badan usaha persekutuan, yang terdiri dari :

a. Perusahaan persekutuan bukan badan hukum, seperti: Persekutuan Perdata, Firma (Fa), Commanditer Venootshaap (CV).

b. Perusahaan persekutuan berbentuk badan hukum: Perseroan Terbatas, Koperasi, Badan Usaha Milik Negara (BUMN), Badan Usaha Milik Daerah (BUMD).

${ }^{1}$ https://lexindone.wordpress.com/2017/03/02/universitas-yang-menyelenggarakan-program-kenotariatan/ diakses 7 -2-2018.

${ }^{2}$ http://www.hukumonline.com/berita/baca/lt5a6b21f72f5a8/kemenkumham-pastikan-mulai-2018-penerimaanmkn-harus-dihentikan 2018. Diakses 7-2-2018. 
Perusahaan perseorangan adalah perusahaan yang modalnya dimiliki oleh perseorangan, termasuk harta bersama dalam keluarga ddalam dijadikan modal perusahaan. Cara pendirian badan usaha perseorangan tidak memerlukan perjanjian dalam mendirikan badan usaha, cukup mengurus Surat Izin Tempat Usaha, dan Surat Izin Usaha Perdagangan.Perusahaan persekutuan merupakan itu perusahaan yang dimiliki oleh beberapa orang yang mempunyai kepentingan sama dan saling bekerja sama. Bekerja sama dapat diartikan kerjasama dalam bidang modal atau kerja sama dalam mengelola perusahaan. Setiap pendirian perusahaan terlebih dahuludiawali oleh kesepakatan para pendiri. Kesepakatan para pendiri harus dibuat dengan akta otentik. Akta Otentik merupakan akta tertulis yang dibuat oleh atau dihadapan notaris.

Berdasarkan Pasal 1 angka 1 UU No. 30 Tahun 2004 menetapkan : Notaris adalah pejabat umum yang berwenang untuk membuat akta otentik dan kewenangan lainnya sebagaimana dimaksud dalam Undang-Undang ini. Akta otentik adalah akta tertulis yang dibuat oleh pejabat umum, yang mempunyai kekuatan pembuktian sangat kuat. Akta Notaris menurut Pasal 1 angka 7 UU No. 30 Tahun 2004 adalah akta otentik yang dibuat oleh atau di hadapan Notaris menurut bentuk dan tata cara yang ditetapkan dalam Undang-Undang ini. Oleh sebab itu akta otentik banyak dipakai dalam transaksi bisnis, seperti: pembuatan akta hak tanggungan, akta perjanjian kredit, akta fidusia, akta jual beli, pendirian perusahaan CV, PT, Koperasi, kegiatan penunjang di pasarmodal, dan sebagainya kegiatan bisnis.

Notaris merupakan salah satu profesi yang eksistensinya dalam bidang pasar modal ditegaskan dalam Pasal 64 Ayat (1) huruf (d) UUPM sebagai salah satu Profesi Penunjang Pasar Modal. Peran penting Notaris dalam kegiatan pasarmodal ditunjukkan dengan pengaturannya dalam UUPM dimana Notaris harus memenuhi kriteria tertentu yang telah diseleksi oleh Menteri Keuangan..

Di dunia perbankan, perjanjian kredit sebagai perjanjian pokok juga dibuat dalam bentuk akta otentik, disamping perjanjian pengikatan jaminan. Membuat Akta Notariil hendaknya Notaris dapat memberikan saran-saran jika terjadi perbedaan pendapat diantara para pihak dengan memberikan masukan kepada mereka tentang bagaimana seharusnya permasalahan itu ditempatkan. Akta Notariil yang dibuat dihadapan Notaris sebagai pejabat umum memiliki pembuktian formal maupun pembuktian material dapat menunjang terhadap tegaknya prinsip kehati-hatian dalam proses pemberian kredit oleh bank. Peran Notaris juga harus ditunjang oleh bank karena sejumlah resiko hukum atas harta kekayaan yang diagunkan oleh debitur sebagai agunan kredit, jika kredit yang diberikan menjadi macet penjualan agunan tidak menimbulkan masalah bagi bank dikemudian hari, hal ini bisa terjadi jika bank kurang cermat dalam mendeteksi status agunan debitur ${ }^{3}$.

Profesi Notaris sangat penting dalam pembuatan akta perjanjian kredit dalam dunia perbankan, Notaris sebagai Pejabat Publik, dituntut profesionalitasnya yang salah satunya adalah menjembatani kepentingan debitur dan kreditur dalam pembuatan akta perjanjian kredit, namun kenyataannya sikap profesionalitas tersebut berhadapan dengan tuntutan dunia perbankan, yaitu adanya efisiensi dalam prosedur perbankan dan keamanan dalam pemberian

${ }^{3}$ http://blog.pasca.gunadarma.ac.id/2012/06/01/peranan-notaris-dalam-perjanjian-kredit-guna-memenuhi-prinsipkehati-hatian-perbankan/ diakses 8-2-2018 
kredit, sehingga dalam praktek lembaga perbankan cenderung menggunakan perjanjian baku dalam perjanjian kreditnya ${ }^{4}$.

Dalam perkembangan dunia bisnis, barang yang berada dalam gudang dapat juga dijadikan jaminan hutang. Dokumen kepemilikan barang yang berada dalam gudang disebut dengan resi. Menurut Pasal 8 ayat (1) Undang-undang Nomor 9 Tahun 2006 tentang Sistem Resi Gudang menetapkan:" Pengalihan Resi Gudang Atas Nama dilakukan dengan akta otentik". Akta otentik dimaksud adalah akta Notaris.

Kemudian ada pada Pasal 8 ayat (2) Undang-undang Nomor 9 Tahun 2006 menetapkan: Pihak yang mengalihkan Resi Gudang memberikan jaminan kepada penerima pengalihan bahwa: a. Resi Gudang tersebut asli; b. penerima pengalihan dianggap tidak mempunyai pengetahuan atas setiap fakta yang dapat mengganggu keabsahan Resi Gudang; c. pihak yang mengalihkan mempunyai hak untuk mengalihkan Resi Gudang;d. penerima pengalihan selanjutnya dibebaskan dari segala tanggung jawab atas kesalahan pengalihan Pemegang Resi Gudang terdahulu; dan e. proses pengalihan telah terjadi secara sah sesuai dengan undang-undang.

Koperasi sebagai salah satu usaha rakyat yang sangat eksis dewasa ini, dan salah satu badan usaha yang masih tangguh meskipun telah terjadi krisis moneter di Indonesia pada tahun 1998. Perkopersian diatur pada Undang-undang No.25 Tahun 1992 tentang Perkoperasian, pada Pasal 9 menetapkan: Koperasi memperoleh status badan hukum setelah akta pendiriannya disahkan oleh Pemerintah. Pemerintah dimaksud adalah Kementerian Perkoperasian. Kesepakatan yang dibuat oleh para pendiri harus dibuat dalam bentuk akta otentik. Kesepakatan para pendiri tersebut dalam bentuk akta otentik harus didaftarkan pada kator yang terkait dengan perkoperasian yang sekarang disebut Kementerian Perkoperasian.

Perseroan Terbatas (PT) yang sekarang diatur pada Undang-undang Nomor 40 Tahun 2007 tentang Perseroan Terbatas memberikan pengertian Perseroan Terbatas, yang selanjutnya disebut Perseroan, adalah badan hukum yang merupakan persekutuan modal, didirikan berdasarkan perjanjian, melakukan kegiatan usaha dengan modal dasar yang seluruhnya terbagi dalam saham dan memenuhi persyaratan yang ditetapkan dalam UndangUndang ini serta peraturan pelaksanaannya. PT adalah perusahaan yang berbentuk badan hukum, maka proses pendiriannya harus sesuai dengan peraturan yang berlaku. Kesepakatan para pendiri haaru di buat dalam bentuk akta otentik, kemudian didaftarkan pada Kementerian Hukum dan HAM.

\subsection{Tingkat pemahaman mahasiswa Fakultas Hukum Universitas Lancang Kuning tentang peran notaris}

Lembaga Penelitian dan Pengabdian Kepada Masyarakat Universitas Jambi, merupakan salah satu lembaga yang mengelola penelitian dan pengabdian kepada masyarakat yang dilakukan oleh para dosen dalam rangka melaksanakan tri darma perguruan tinggi. Salah satu tridarma perguruan tinggi adalah melakukan pengabdian masyarakat selain mengajar dan meneliti. ${ }^{4}$ http://notarisrinto.id/2016/11/26/fungsi-dan-manfaat-profesi-notaris-untuk-pembuatan-akta-notariil-dalam-
suatu-perjanjian-kredit-perbankan/ diakses 7-2-2018 
Universitas Jambi telah menetapkan visi yaitu " menjadi universitas berstandar global yang berjiwa kewirausahaan pada tahun 2025". Salah satu dari visi Universitas Jambi yaitu “ menjadi universitas berstandar global yang berjiwa kewirausahaan pada tahun 2025". Relevan kiranya dilakukan penyuluhan atau sosialisasi kepada Fakultas lain diluar Propinsi Jambi untuk dilakukan penyuluhan tentang peran notaris dalam dunia bisnis. Dari hasil pengabdian dalam bentuk sosialisasi ini diharapkan bertambah minat mahasiswa untuk mlanjutkan pendidikan di Prodi Magister Kenotariatan Pasca Sarjana Universitas Jambi.

Dilihat dari beberapa pertanyaan yang duajuak peserta terlihat antusias dan minta kelompok sasaran untuk mengetahui peran notaris dalam pembutan akta dibidang bisnis. Dari 54 kuisiner yang beredar dan dikumpul menunjukan bahwa $70 \%$ responden berminat untuk melanjutkan pendidikan ke Prodi Magister Kenotariatan, Cuma ada 20\% presen responden merasa terkendala oleh biaya pendidikan. Dari jawaban responden menjawab bahwa profesi notaris dalam transaksi bisnis merupakan profesi masa depan yang menjanjikan, karena mereka milihat gaya kehidupan para notaris yang dilihatnya dapat memberikan kesejahteraan. Disamping itu, profesi Notaris merupakan salah satu profesi yang dapat menciptakan lapangan kerja .

\section{KESIMPULAN DAN SARAN}

3.1.Peran notaris dalam pembuatan kontrak bisnis sangat dibutuhkan sekali terutama dalam pembuatan kontrak bisnis. Akta yang dibuat oleh notaris berbentuk akta otentik, maka kekuatan pembuktinya sempurna. Maka para pembisnis untuk mewujudkan kepastian hukum lebih aman membuat akta notaris.

3.2.Respon mahasiswa terhadap profesi notaris dewasa ini, mendapat tanggapan positif, karena profesi Notaris merupakan profesi bergensi, karena ia adalah pejabat umum. Profesi Notaris lebih mudah mendapatkan pekerjaan.

\section{DAFTAR PUSTAKA}

Undang-undangNomor 30 tahun 2004 tentangJabatanNotaris

Undang-undangNomor 2 tahun 2014 tentangPerubahanatasUndang-undangNomor 30 tahun 2004 tentangJabatanNotaris

Undang-undangNomor 4 Tahun 1996 tentangHakTanggungan

Undang-undangNomor 42 Tahun 1999 tentangJaminanFidusia

Undang-undangNomor 21 Tahun 1992 tentangPelayaran

Undang-undangNomor 9 Tahun 2006 tentangSistemResiGudang

Undang-undangNomor 9 Tahun 2011 tentangPerubahanUndang-undangNomor 9 Tahun 2006 tentangSistemResiGudang

KitabUndang-undangHukumPerdata

Undang-undangNomor 8 Tahun 1995tentang Pasar Modal 
Undang-undangNomor 25Tahun 1992tentang Perkoperasian

Undang-undangNomor 16 Tahun 2001tentang Yayasan

Undang-undangNomor 28 Tahun 2004 tentangPerubahanAtasUndang-undangNomor 16 Tahun 2001tentang Yayasan

Undang-undangNomor 40 Tahun 2007 tentang Perseroan Terbatas.

https://lexindone.wordpress.com/2017/03/02/universitas-yang-menyelenggarakan-programkenotariatan/ diakses 7 -2-2018.

http://www.hukumonline.com/berita/baca/lt5a6b21f72f5a8/kemenkumham-pastikan-mulai2018-penerimaan-mkn-harus-dihentikan 2018. Diakses 7-2-2018.

http://blog.pasca.gunadarma.ac.id/2012/06/01/peranan-notaris-dalam-perjanjian-kredit-gunamemenuhi-prinsip-kehati-hatian-perbankan/ diakses 8-2-2018

http://notarisrinto.id/2016/11/26/fungsi-dan-manfaat-profesi-notaris-untuk-pembuatan-aktanotariil-dalam-suatu-perjanjian-kredit-perbankan/ diakses 7-2-2018 